\title{
The Comparative Study on Management of School-based Curriculum in South Korea and China
}

\author{
Li Xiaohui1)
}

\begin{abstract}
In order for schools to be effective in teaching guidance, it is necessary to support the process of organizing, operating, and evaluating the school curriculum effectively and efficiently. Effective support and maintenance of this process can be regarded as curriculum management. The operation of school curriculum is one of the curriculum management. In a broad sense, it is educational activity itself, but in the narrow sense it is classroom operation. The purpose of this study is to analyze what kind of difference exists between Korea and China in school curriculum in terms of school curriculum management plan. The process of planning the school curriculum is divided into planning stage, practice stage, and evaluation stage.
\end{abstract}

Keywords: School-based Curriculum, Operation Method, China, Comparative Study, Management

\section{Introduction}

In order for schools to effectively guide their education, it is necessary to help them effectively and efficiently operate a series of courses in the compilation, operation and evaluation of school curriculum. Effective support and maintenance of these courses can be seen as curriculum management. The tasks of selecting students, organizing faculty members, supporting the operation of curriculum in schools, focusing on the preparation and execution of school budgets, and investigating the needs of parents and others for school education are a series of activities aimed at achieving the goal of curriculum management. The operation of the curriculum in a broad sense is itself a educational activity, but the operation of the curriculum in a narrow sense is a classroom operation[1].

South Korea and China have historically conducted exchanges in many ways. Especially, since Korea and China established diplomatic ties in 1992, bilateral exchanges have been carried out in various ways, including economy, industry, politics, society and culture. As Korea-China

Received(April 16, 2019), Review Result(1st: May 3, 2019, 2nd: June 27, 2019), Accepted(September 10, 2019)

1) (Student) 41566 Department of Education, Kyungpook National University Daegu, Korea email: lovely824hui@msn.cn 
exchanges enter 2019, I think there is a need to explore more creative ways to get into new stages for longer-term and future development.

South Korea has common ground that education belongs to the world's leading countries and all of them are located in Asia, like China. Korea is also ahead of China in education competitiveness. In this context, this study attempts to analyse what operational differences exist in school curriculum in terms of school curriculum management plan. The operation planning procedures of the school curriculum were analyzed by subdividing into planning, implementation and evaluation stages, and differences related to the operation of each curriculum were explored.

So, according to the direction of the school curriculum operation plan, the following research problems were set up and designed to resolve these.

First, look at the operation plan of the school curriculum in South Korea.

Second, look at China's school curriculum management plan.

Third, explore the similarities and differences between the school curriculum management plans in South Korea and China.

\section{The Concept of School Curriculum Operation Plan}

\subsection{The Purpose of Operation}

The operation of the curriculum refers to the overall development of the curriculum and the overall process of the organization, i.e. from conceptualization of the initial curriculum to decision and adoption to renewal[2]. To be exact, it collectively refers to a series of courses that support and facilitate the implementation of curriculum in the use and practice of curriculum in schools and classrooms. Therefore, the operational issues include those related to efficient and systematic implementation of the curriculum. This refers to the maintenance and management of the conditions (data, personnel, organization, administration and finance, facilities, training, and training) that support and promote the application of developed curriculum to school sites. Thus, the implementation of the curriculum means aspects of development and utilization, and the operation means aspects of management.

Therefore, curriculum operation has the nature of curriculum management. Curriculum management refers to adjustment of manufacturing conditions in schools to effectively organize and operate curriculums to achieve educational goals. In order for schools to effectively guide their education, schools need to efficiently support and maintain a series of courses in the 
compilation, operation and evaluation of school curriculum.

Most of education curriculums are newly developed and revised, either fully or partially modified. If the education curriculums are largely divided into research and development, implementation and operation, evaluation and improvement, then the implementation and operation are the process of practicing a curriculum that has been developed and at the same time a support system of execution. The operation of a curriculum in a broad sense is the operation of the curriculum itself, but in a narrow sense, classroom operation[1].

\subsection{Curriculum Operation and Teacher}

Teacher is a curriculum. In other words, all kinds of educational activities such as teacher instruction and student life guidance are the curriculum that students experience. The curriculum is a teacher. In other words, it is up to the teachers to operate entirely that the curriculum is operated at a higher or lower quality than the original. Therefore, the quality of education is the quality of teachers[1].

The method and effect of curriculum management are different depending on the development stage and degree of teacher. Teachers change as teachers have more career as pre-teachers, beginning teachers, middle-level teachers, and elderly teachers. The direction of teacher change may be either a direction in which expertise and autonomy is improved or a direction in which it is degraded. The teachers' expertise can be changed as they change their teaching grade-level or as they are promoted to higher position such as vice principal or principal.

Many people are involved in the operation of the school curriculum. Principals, informal leaders, and other teachers can influence the operation of the curriculum. In particular, the principal plays a major role in determining the quality of school curriculum operation. The principal has a strong influence and many teachers are influenced by his views.

\subsection{The School-based Curriculum Operation Plan and Education Curriculum Operation}

In modern society, no matter what you do, you need a plan. Planning can be seen as a deliberate act to achieve a specific purpose efficiently. Such plans have been implemented in schools through the establishment of school curriculum management plans, education plans, or school education plans.

The school education plan is the first step in the school curriculum, which includes a 
comprehensive plan for the school curriculum and its operation, by setting up school education goals and designing the entire course of organization, activity and evaluation to achieve them.

As a step to identify the problems for establishing education plans, the school will analyze the problems of education based on the needs of education and the current education. After the problem is identified, the school aims and policies will be set and the implementation plan will be established accordingly. The promotion plan is a measure for implementing school goals and policies, and is designed to be implemented in conjunction with the budget for each organization. Next, the organization that implements the implementation plan will be planned, and finally the assessment plan will be established.

\section{The Social Background and Educational System of Comparative Countries}

\subsection{The Social Background of South Korea and China}

China is one of the largest countries in the world, with a land area of about 9.6 million square kilometers, or 6.5 percent of the Earth's land area. As of 2019, China's total population stood at 13.90 billion. China is a traditionally agricultural country. China's economy is a socialist market economy based on national agendas. The State Organizations of the Republic of China include 1 National Authority of Power, National People's Congress and 2 State Councils of Local People's Congress at each stage, 3 People's Courts of People's Government at each stage, 4 National Law Watchmen and People's Administrative Officers.

When it comes to traditional culture, South Korea and China tend to adhere to tradition, which values traditional education based mainly on Confucian culture. In this regard, Korea and China have traditionally placed importance on family education, and Confucian scriptures such as the Book of 四書三經, which were used in Confucian culture, were mainly used as education guidelines. However, China's Cultural Revolution and Korea's loss of sovereignty in the early 20th century cut off or tarnished traditional culture and values. The social background of each era is different, but there is also one thing in common, whether in Korea or China, that we have neglected family education due to the quantitative growth of school education and the change in social structure[3].

South Korea and China have something in common in their pursuit of intrinsic values in the culture of Buddhism and Confucianism. The similarity is that the educational zeal for children is high through cultural perceptions and customs formed between the two countries. However, compared to Korea's deep connection with competition among the same ethnic groups, the 
difference in experience, tradition and culture appears to be significant in China's difference of being a multi ethnic nation comprising 56 ethnic minorities. This has led to diversity in Chinese social culture. This effect is different from Korea in education and social system.

\subsection{The Educational System of South Korea and China}

China's education system has been greatly influenced by history and social culture. In other words, the education system of slave society, the education system of feudal society, the education system of the semi-bonggun and semi-colonial branch, and the education system of the 老解放區, the current socialist school system has been developed, which includes equality, harmony of unity and diversity, the combination of supply and upgrade, association, ethnicity, and separation of schools and religions[4].

China's education system is divided into four categories. That is, basic education, technical and vocational education, higher education, and adult education. Basic education includes pre-school education, regular elementary school education and secondary education Technical and vocational education is mainly conducted in special secondary schools, technical writing schools, secondary vocational schools, and advanced technology and vocational colleges. Higher education basically refers to education conducted by regular higher education institutions, and adult education refers to various forms of schooling and education aimed at adults.

China's current school system in an overview, it is divided into ten varieties. That is, kindergarten education, elementary school education, ordinary middle school, vocational skill education, private education, secondary education, higher education, adult education, minority education and special education.

Looking at Korea's history of educational development, it was influenced by historical and political influences just like China.. South Korea's current school system is divided into four varieties. That is, pre-school education, primary education, secondary education, and higher education.

The two countries have similarities and differences in terms of education system, but it is similar that the ultimate purpose and establishment background of the education is to pursue national ideology education and national development.

\section{The Comparison of School-based Curriculum Operation Methods}

\subsection{Chinese School-based Curriculum}


Looking at the history of Chinese curriculum development, it has been an old tradition that national curriculum was conducted nationwide on a uniform basis. In the 20th century, China began to reform its curriculum. Based on the experience of the decentralization system country, China's educational process reform has divided the rights of local education courses while maintaining traditional central government, and through a series of educational process reforms, it has created a curriculum with a distinctive feature. At present, national level curriculum exists in China, and the basic curriculum system at the Chinese national level includes infant education, compulsory education and general-class high school education.

In 2001, the Chinese Ministry of Education proclaimed its Decision on the Reform and Development of Basic Education. Decisions on the Reform and Development of Basic Education concluded that "to promote the reform of basic education, we implement adjustment and reform of a series of contents, including the curriculum system related to basic education, the implementation and operation of curriculum, and the evaluation of curriculum, and the implementation of new curriculum that meets the standards of the whole education." Decision on the Reform and Development of Basic Education decided that "education courses implement a 'class 3 curriculum management system' - national curriculum, regional curriculum and school curriculum for guarantee and promotion in meeting local, school and student needs." The Ministry of Education has organized a bias and time dividend for basic education courses, established national curriculum standards and actively implemented a curriculum evaluation system[5].

\subsection{South Korea School-based Curriculum}

South Korea's development of school curricula has been publicized a total of nine times amid the strengthening and easing of the national curriculum. The education curriculum compilation and operation system was divided into national, regional and school levels so that it could be organized and operated as a national standard curriculum, regional education and operation guidelines, and a unit school curriculum. These 2015 revised curriculum covers both national-level curricula that the Education Ministry publishes in accordance with law, guidelines for organizing and operating curriculum programs by municipal and provincial education offices, and school-level curricula.

If you look at the general composition of the school curriculum, it may appear as shown in the following [Table 1][6]. 
[Table 1] The System of School Curriculum

I. The Direction of School Curriculum Operation

1. The nature of the school curriculum

2. The school's educational goals and emphasis on efforts

3. Compilation and time allocation

4. Fundamental Principles of Composition

5. Basic Direction of Operations

II. Mapping of curricula, discretionary activities and special activities

1. Curriculum (grade, instruction by subject)

2. discretionary activities (objectives, content, methods, assessment)

3. Special activities (operating by area and grade)

III. Evaluation of the School Curriculum

1. subject

2. discretionary and special activities

3. Organizing and operating school curriculum

Appendix (or school management support system)

\subsection{The School-based Curriculum Plans in South Korea}

Since the Korean Educational Development Institute developed a planning-level model for the school management system, various scholars have included the basics of education plans, educational goals and policies, organizational plans, management activities plans, and evaluation plans, although the sequence and content of the school management system are slightly different at the stage of the school education plan[3].

[Table 2] School Operation Planning Model

\begin{tabular}{|c|c|c|c|}
\hline \multirow{4}{*}{$\begin{array}{c}\text { School } \\
\text { Operation } \\
\text { Planning Model }\end{array}$} & \multirow{4}{*}{ Design stage } & Problem investigation & $\begin{array}{l}\text { Higher goals, scholarship policy, } \\
\text { regional status, management status }\end{array}$ \\
\hline & & $\begin{array}{l}\text { Setting goals and } \\
\text { policies }\end{array}$ & $\begin{array}{l}\text { Educational goals, management goals, } \\
\text { and management policies }\end{array}$ \\
\hline & & Organizational plan & $\begin{array}{l}\text { Educational guidance organization, } \\
\text { head of the school, operation } \\
\text { consultation organization, local history } \\
\text { organization }\end{array}$ \\
\hline & & Activity plan & $\begin{array}{c}\text { Education process management } \\
\text { (teaching plan, special map, living } \\
\text { map), } \\
\text { Education staff job development } \\
\text { (research, training), } \\
\text { Education condition management }\end{array}$ \\
\hline
\end{tabular}




\begin{tabular}{|l|c|c|c|}
\hline \multirow{2}{*}{} & & (personnel, finance, resources) \\
\cline { 2 - 3 } & \multicolumn{2}{|c|}{ Evaluation plan } & $\begin{array}{c}\text { Input evaluation, process evaluation, } \\
\text { and calculation evaluation }\end{array}$ \\
\cline { 2 - 3 } & Evaluation stage & Stage of action \\
\hline
\end{tabular}

\subsection{The School-based Curriculum Plans in China}

Four basic conditions are needed to operate the school curriculum in China. First, it is a clear school education philosophy. In looking at the policy of education, the state makes basic regulations on the educational goals of each level of schools and the following. These regulations do not define the characteristics of each school, but provide only a framework for basic educational goals. Each school has a different management policy and guidelines for its own school. Second, the formation of a national and open school organization is necessary. The school curriculum management plan is a product of the educational philosophy of each school. Among them, the role of a person is more important than anything else. In particular, the principal's role is more important. Looking at the results of various studies, a school director needs to actively create an open and ethnic school management consulting organization if he wants to reform schools effectively within the school. Third, there is a need to build an education system that displays school philosophy and features. Various conditions need to be considered, such as the school's philosophy of education, educational goals, teachers' opinions, and the demands of students and parents, to operate the school curriculum effectively. Fourth, the evaluation system within the school is necessary[7].

Under these basic conditions, school curriculum management was often divided into planning, implementation and evaluation levels, as was the case with schools in China. Among them, the contents of documents related to classroom operation were presented more than anything else in the operation of the school curriculum. In the 21st century, which emphasizes the convergence of knowledge more, the school stresses the convergence of teaching and studies and practices the convergence of subjects.

\section{Conclusion}

With the recent emergence of the term "fourth industrial revolution," the world is making 
attempts and moves to achieve a new era in response. Political, economic, social, cultural and environmental sectors are all interrelated with and moving with the whole planet as a whole. The issue of education is also becoming an important issue as it relates to the global community as a whole. None of the views, purposes, content, or methods of education are based on globalization.

Korea and China are also closely related to the world, it is not possible to take an independent line just because it is an educational field. Although the article failed to focus on analyzing how school curricula are run or discussing technological engineering developments and future positive changes, looking at the plans for school curriculum management in Korea and China will highlight the plans that reflect expectations of who students should become in the future, the content and methods of education needed to foster them as such, and the evaluation of their performance.

Whether it is in Korea or China, the school curriculum management plan exists as a guidebook, reflecting expectations of who students should become in the future, the content and methods of education needed to nurture them as such, and the evaluation of educational performance.

Korea and China operate and organize school-level curricula by localizing them based on national-level curriculum in a centralized manner as an oriental country. So, the following are the implications of comparing the way Korean and Chinese schools operate their curriculum.

First, the quality of learners' educational experience should be planned and implemented from a comprehensive perspective, including content, methods, assessments and actual management, in relation to the curriculum in Korea or China. Whether it is in Korea or China, it provides regional and school curricula based on the national curriculum. In particular, efforts should be made to increase diversity, convergence, and elasticity of the curriculum by taking into account regional characteristics in the compilation and operation of school curricula.

Second, the management of curriculum operations should be streamlined. Above all, we should conduct a student-centered curriculum. In particular, the curriculum should be run in a way that matches the individuality and aptitude of students.

Third, when planning the operation of a school curriculum, it should be a school-level plan by setting the quantity, composition system, and emphasis on education, and it is necessary to be careful not to become an absolute formal document. Efforts will be made to plan the operation of the school curriculum to achieve true school education. 
The Comparative Study on Management of School-based Curriculum in South Korea and China

\section{References}

[1] Kang Hyun-suk, Curriculum Management, Explore the Current Curriculum, Hakjisa, (2011)

[2] T. Husén, T. N. Postlethwaite, The International Encyclopedia of Education, 2nd Edition, Pergamon, pp.1320-1325, (1994)

[3] Jeong Tae-beom, School Management Planning Theory, Yang Seo Won, (1998)

[4] Baek Jongeok, Educational Administration System of Major Countries, Kyoyookbook, (1996)

[5] Ministry of Education, Basic Education Curriculum Reform Program (Trial), www.moe.gov.cn/srcsite/A26/jcj_kcjcgh/200106/t20010608_167343.html, (2001)

[6] Kwon Nak-won, Min Yong-sung, Choi Min-jung, Development of school curriculum: How to understand and develop school curriculum, Hakjisa (2008)

[7] Cui Yunhuo, The Development of School-based Curriculum: Theory and Practice, Beijing Education Press, https://xueshu.baidu.com/usercenter/paper/show?paperid=e99c572f309b0950ded2b4ce968912ad\&site=xueshu_se, (2000) 